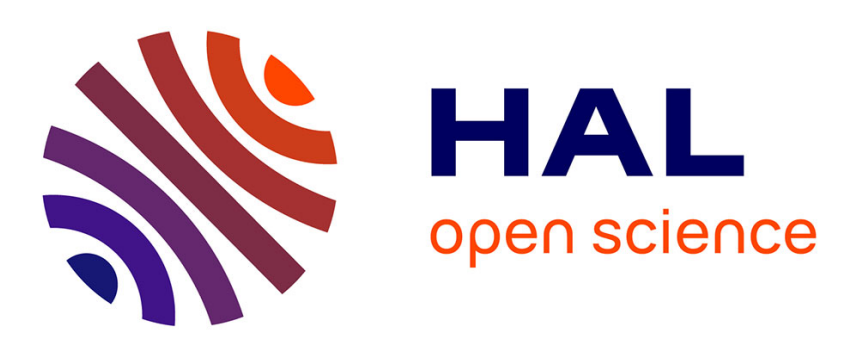

\title{
Computational suite of models with heterogeneous agents: Multi-country real business cycle models
}

\author{
Wouter J. den Haan, Kenneth L. Judd, Michel Juillard
}

\section{To cite this version:}

Wouter J. den Haan, Kenneth L. Judd, Michel Juillard. Computational suite of models with heterogeneous agents: Multi-country real business cycle models. Journal of Economic Dynamics and Control, 2010, 35 (2), pp.175. 10.1016/j.jedc.2010.09.010 . hal-00765828

\section{HAL Id: hal-00765828 \\ https://hal.science/hal-00765828}

Submitted on 17 Dec 2012

HAL is a multi-disciplinary open access archive for the deposit and dissemination of scientific research documents, whether they are published or not. The documents may come from teaching and research institutions in France or abroad, or from public or private research centers.
L'archive ouverte pluridisciplinaire HAL, est destinée au dépôt et à la diffusion de documents scientifiques de niveau recherche, publiés ou non, émanant des établissements d'enseignement et de recherche français ou étrangers, des laboratoires publics ou privés. 


\section{Author's Accepted Manuscript}

Computational suite of models with heterogeneous agents: Multi-country real business cycle models

Wouter J. Den Haan, Kenneth L. Judd, Michel Juillard

PII: S0165-1889(10)00214-9

DOI: doi:10.1016/j.jedc.2010.09.010

Reference: DYNCON 2484

To appear in: Journal of Economic Dynamics \& Control

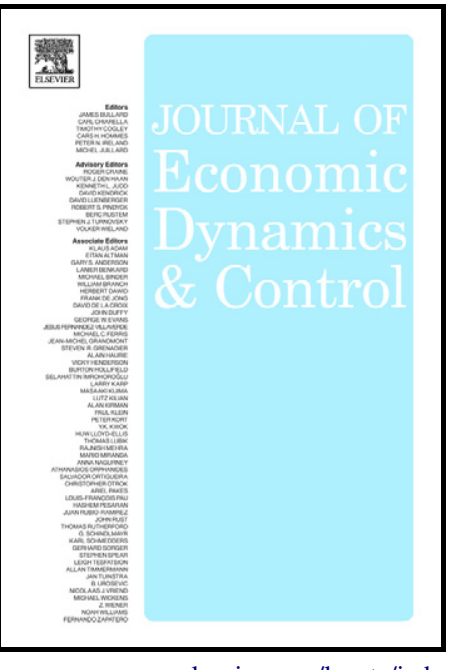

www.elsevier.com/locate/jedc

Received date: 24 August 2010

Accepted date: 24 August 2010

Cite this article as: Wouter J. Den Haan, Kenneth L. Judd and Michel Juillard, Computational suite of models with heterogeneous agents: Multi-country real business cycle models, Journal of Economic Dynamics \& Control, doi:10.1016/j.jedc.2010.09.010

This is a PDF file of an unedited manuscript that has been accepted for publication. As a service to our customers we are providing this early version of the manuscript. The manuscript will undergo copyediting, typesetting, and review of the resulting galley proof before it is published in its final citable form. Please note that during the production process errors may be discovered which could affect the content, and all legal disclaimers that apply to the journal pertain. 


\title{
Computational Suite of Models with Heterogeneous Agents: Multi-Country Real Business Cycle Models
}

\author{
Wouter J. Den Haan, Kenneth L. Judd† and Michel Juillard ${ }^{\ddagger}$
}

September 27, 2010

\begin{abstract}
This paper describes the second model considered in the computational suite project that compares the performance of different numerical algorithms. It is a multi-country model in which countries face different productivity shocks. Solving such models is a challenging numerical problem unless the number of countries is small. The solutions are functions of a large set of arguments and the functional forms are unknown. Moreover, the solution procedures have to deal with high-dimensional integration problems.
\end{abstract}

Key Words: Numerical solutions, simulations, approximations

JEL Classification: C63

\footnotetext{
*Amsterdam School of Economics, University of Amsterdam, Amsterdam, the Netherlands and CEPR; wdenhaan@uva.nl.

${ }^{\dagger}$ Hoover Institution, Stanford University, Stanford, California, USA and NBER; judd@hoover.stanford.edu.

${ }^{\ddagger}$ Corresponding author. Banque de France, 31 Rue Croix des Petits Champs, 75001 Paris, France and CEPREMAP; michel.juillard@ens.fr
} 


\section{Introduction}

The recent financial crisis has triggered a surge in research using dynamic stochastic general equilibrium (DSGE) models that go beyond the representative agent paradigm. The representative agent model is based on the assumption that asset markets are frictionless, an assumption that is unlikely to be useful when thinking about serious economic fluctuations. Models with heterogeneous agents, information asymmetries, contracting problems, matching frictions, incomplete markets, anticipated shocks, and adjustment costs have not been neglected by the profession, but the recent crisis has triggered a surge in the number of economists exploring models with these features. This shift can only have increased the relevance of the models in our computational suite, since they all go beyond the representative-agent paradigm in non-trivial dimensions.

The first model that we considered in the computational suite project contained a continuum of heterogeneous agents, idiosyncratic income shocks, incomplete financial markets, and aggregate uncertainty. ${ }^{1}$ The model analyzed in this special issue contains a finite number of agents (countries) and several different stochastic variables affecting the system. As the number of agents in the model grows, the dimension of the state space expands. Moreover, forming expectations entails integrating over a higher-dimensional set of shocks when there are more sources of uncertainty. Both features make it more difficult to obtain numerical solutions. One of the key questions to be answered is how many state variables and how many random variables the different algorithms can handle, that is, provide an accurate answer in a reasonable amount time.

The maximum number of agents considered in this special issue is equal to ten, which seems quite reasonable for a multi-country model. In that case there are eleven sources of uncertainty affecting the ten productivity levels, namely ten country-specific productivity shocks and a worldwide shock. Since the productivity level and the capital stock of each country are state variables, there are twenty state variables when there are ten countries.

Kollmann, Maliar, Malin, and Pichler (2010) compare the results generated by the different algorithms. Not surprisingly, they find that there is a trade off between speed

\footnotetext{
${ }^{1}$ See Den Haan, Judd, and Juillard (2010).
} 
and accuracy. There are fast algorithms, where fast means obtaining a solution in seconds. These algorithms generate solutions that (in all cases considered) are accurate in terms of the implied business cycle moments, but are not accurate in all possible dimensions examined. There are also algorithms that can obtain an accurate solution in basically all dimensions considered, but then the running time would be at least an hour for the model with ten countries. ${ }^{2}$ In practice, the user will have to decide on the combination of speed and accuracy that is appropriate for the question at hand.

The model with ten different countries and eleven sources of uncertainty is in several dimensions more complex than the model with a continuum agents considered in the first computational suite, described in Den Haan, Judd, and Juillard (2010). In that model the conditional expectations are integrals over only two random variables, namely the idiosyncratic and the aggregate random variable. Moreover, even though the set of state variables contains the cross-sectional distribution, an infinite-dimensional object, it can be approximated well with a small set of moments. Consequently, the actual set of state variables used did not come close to twenty, the number of state variables in the model with ten countries.

The following papers are included in the special issue. Juillard and Villemot (2010) describe and motivate the accuracy tests used to evaluate the different algorithms. They also give the exact set of model specifications considered. Kollmann, Maliar, Malin, and Pichler (2010) compare the properties of the different algorithms and give a brief description of the different algorithms. More detailed descriptions of the algorithms can be found in Kollmann, Kim, and Kim (2010), Malin, Krueger, and Kubler (2010) Maliar, Maliar, and Judd (2010), and Pichler (2010).

\section{The multi-country model}

The structure of the model is very simple, namely a social planner's problem that maximizes a weighted average of the utility levels of $N$ agents (countries), where each agent

\footnotetext{
${ }^{2}$ Running time does not only depend on the number of countries, but also on other aspects of the model specifciation and, of course, on the algorithm used. The longest running time reported is equal to 44 hours.
} 
has a production technology of which the productivity is stochastic. That is,

$$
\begin{gathered}
\max _{\left\{c_{t}^{j}, l_{t}^{j}, k_{t+1}^{j}, l_{t}^{j}\right\}_{j, t}} \mathrm{E}_{0} \sum_{j=0}^{N} \tau^{j}\left(\sum_{t=0}^{+\infty} \beta^{t} u^{j}\left(c_{t}^{j}, l_{t}^{j}\right)\right) \\
\text { s.t. } \\
k_{t+1}^{j}=(1-\delta) k_{t}^{j}+i_{t}^{j} \\
\Gamma_{t}^{j}=\frac{\phi}{2} k_{t}^{j}\left(\frac{i_{t}^{j}}{k_{t}^{j}}-\delta\right)^{2} \\
\sum_{j=1}^{N}\left(c_{t}^{j}+i_{t}^{j}-\delta k_{t}^{j}\right)=\sum_{j=1}^{N}\left(a_{t}^{j} f^{j}\left(k_{t}^{j}, l_{t}^{j}\right)-\Gamma_{t}^{j}\right)
\end{gathered}
$$

where $c_{t}^{j}$ is the consumption of agent $j, k_{t}^{j}$ is the beginning-of-period capital stock of agent $j, i_{t}^{j}$ is the investment of agent $j$, and $\Gamma_{t}^{j}$ are the investment adjustment cost of country $j$. Productivity in country $j, a_{t}^{j}$, is an exogenous random process and its law of motion is given by

$$
\ln a_{t}^{j}=\rho \ln a_{t-1}^{j}+\sigma\left(e_{t}+e_{t}^{j}\right)
$$

where $e_{t}$ is the worldwide shock and $e_{t}^{j}$ the country-specific shock. Juillard and Villemot (2010) derive the first-order conditions and also specify all the functional forms and parameter values considered.

Despite its simplicity, this model is a good candidate for the computational suite. In fact, it is exactly the simplicity that allows us to focus on two important numerical challenges to solve DSGE models. Those challenges are incorporating many state variables and allowing for many sources of uncertainty.

\section{References}

Den HaAn, W. J., K. L. Judd, and M. Juillard (2010): "Computational Suite of Models with Heterogeneous Agents: Incomplete Markets and Aggregate Uncertainty," Journal of Economic Dynamics and Control, 34, 255-266.

Juillard, M., and S. Villemot (2010): "Multi-Country Real Business Cycle Models: 
Accuracy Tests and Test Bench," Journal of Economic Dynamics and Control, this issue.

Kollmann, R., J. Kim, and S. H. Kim (2010): "Solving the Multi-Country Real Business Cycle Model Using a Peturbation Method," Journal of Economic Dynamics and Control, this issue.

Kollmann, R., S. Maliar, B. A. Malin, and P. Pichler (2010): "Comparison of Solutions to the Multi-Country Real Business Cycle Model," Journal of Economic Dynamics and Control, this issue.

Maliar, S., L. Maliar, And K. J. Judd (2010): "Solving the Multi-Country Real Business Cycle Model Using Ergodic Set Methods," Journal of Economic Dynamics and Control, this issue.

Malin, B. A., D. Krueger, and F. Kubler (2010): "Solving the Multi-Country Real Business Cycle Model Using a Smolyak-Collocation Method," Journal of Economic Dynamics and Control, this issue.

Pichler, P. (2010): "Solving the Multi-Country Real Business Cycle Model Using a Monomial Rule Galerkin Method," Journal of Economic Dynamics and Control, this issue. 